\title{
AN INTRODUCTION TO SECTION 15(1) OF THE CHARTER*
}

\author{
T. W. WAKELING**
}

\begin{abstract}
This article will discuss briefly the rationale for s. 15(1), its origins and peculiar features and consider the lines of inquiry which will prove most useful in assessing the constitutionality of laws subject to a s. 15(1) challenge.
\end{abstract}

\section{INTRODUCTION}

Section 15(1) of the Canadian Charter of Rights and Freedoms' states that "Every individual is equal before and under the law and has the right to the equal protection and equal benefit of the law without discrimination and, in particular, without discrimination based on race, national or ethnic origin, colour, religion, sex, age or mental or physical disability." It reflects a basic human desire that those who make decisions which affect the enjoyment of life, treat those similarly situated alike and those who are not alike differently. ${ }^{2}$ As the Ontario Court of Appeal has stated, it is an "important principle of justice that equals should receive equal treatment." ${ }^{3}$ To demand less of decision makers invites the risk that those treated differently will think less of themselves. With regard to religious differences, Mr. Justice Dickson stated in The Queen v. Big M Drug Mart, ${ }^{4}$ "The theological content of the legislation remains as a subtle and constant reminder to religious minorities within the country of their differences with, and alienation from, the dominant religious culture."

Section 15 applies to legislators and their delegates. However, the principle it represents often accounts for many of the decisions persons make in life as spouses, parents and partners to name but a few roles. For example, a parent who puts the four year old to bed at the same time as the fifteen month old toddler will likely hear the older one complain, "Why do I have to go to bed when the baby does?" The older child feels his age entitles him to a later bedtime. The parent who is not swayed by this plea has likely concluded that age is not a relevant factor, that the need for sleep is and that a common bedtime ensures both children the necessary sleep they need to grow up healthy and strong. It may be the case that the baby has a morning nap which the older one misses. If the parent is without a good explanation, the child's remonstrance will likely prompt some unease in the parent enforcing the arbitrary common bedtime.

Or a law partnership compensation committee may strive to allot partnership interests on an equitable basis and attempt to ensure that those who make a substantially similar contribution to the partnership receive

* This article was presented as a paper at a series of seminars on section 15 of the Charter sponsored by the Friends of the Faculty of Law. It was delivered on Wednesday, January 8 , 1986. The text has since been amended.

* B.A., LL.B., LL.M., Partner in firm of Milner \& Steer, Edmonton, Alberta.

1. Constitution Act, 1982, as enacted by Canada Act 1982 (U.K.), 1982, c. 11.

2. See The Queen v. Oakes (1986) 65 N.R. 87 (S.C.C.); Kask v. Shimizu, unreported, 11 April 1986, J.D. of Edmonton, 8303-15705 (Alta. Q.B.).

3. Re McDonald and The Queen (1985) 51 O.R. (2d) 745 at 768 . See also The Queen v. Big $M$ Drug Mart Ltd. [1985] i S.C.R. 295 at 336.

4. Id. at 337 . 
the same reward. It knows that its failure to treat likes alike or those not alike differently will breed discontent and jeopardize the well-being of the firm.

What we strive for as parents and partners, namely, fairness, reasonableness and consistency, we expect of our legislators and through s. 15(1) of the Charter direct our courts to enforce legislative compliance with that standard.

This devotion to equality should not be misunderstood as a societal or an individual plea for laws or decisions devoid of classification systems. ${ }^{5}$ American and Canadian courts long ago specifically acknowledged the legitimacy of these schemes. In F.S. Royster Guano Co. v. Virginia, ${ }^{6} \mathrm{Mr}$. Justice Pitney observed that:

It is unnecessary to say that the "equal protection of the laws" required by the Fourteenth Amendment does not prevent the States from resorting to classification for the purposes of legislation. Numerous and familiar decisions of this court establish that they have a wide range of discretion in that regard.

Mr. Justice McIntyre said much the same thing sixty years later in MacKay v. The Queen:'

\begin{abstract}
It seems to me that it is incontestable that Parliament has the power to legislate in such a way as to affect one group or class in society as distinct from another without any necessary offence to the Canadian Bill of Rights. The problem arises however when we attempt to determine an acceptable basis for the definition of such a separate class, and the nature of the special legislation involved. Equality in this context must not be synonymous with mere universality of application. There are many differing circumstances and conditions affecting different groups which will dictate different treatment.
\end{abstract}

A more recent testimonial to this viewpoint is our Charter. It is replete with examples where rights have been granted to groups with special characteristics. Obviously the Charter's makers realized that the attainment of legislative goals was not always dependent on regulating the activities of all within the jurisdiction. For example, citizens enjoy rights which noncitizens do not. Section 3 bestows on citizens the right to vote for members of the House of Commons. And s. 23(1)(a) is even more particular singling out for special treatment "Citizens of Canada (a) whose first language learned and still understood is that of the English or French linguistic minority population of the province in which they reside. ..."

Denying lawmakers this legislative tool would have serious consequences. Legislators must be free to affect the conduct of only those persons whose acts will have some bearing on the achievement of legislative objects. If the contrary were the case, legislators would have to restrict attention to matters which lent themselves to universal rules. Traffic regulations requiring traffic to use the right-hand side of the road would be an example of a universal rule. So would a criminal law making homicide an offence.

5. See Tit v. The Director of Vital Statistics, unreported, 21 April 1986, Winnipeg Centre, 8601-09012 (Man. Q.B.) at 4.

6. 253 U.S. 412 at 415 (1920).

7. [1980] 2 S.C.R. 370 at 406 . See also British Columbia \& Yukon Territory Bldg. \& Constr. Trades Council v. British Columbia (1985) 66 B.C.L.R. 279 at 288 (S.C. Chambers); R. v. Doucette, unreported, 29 November 1985, County of Halifax (N.S. Prov. Ct.) at 22. 


\section{THE PROGENITORS OF SECTION 15}

Section 15(1) incorporates four equality concepts. First, every individual is equal before the law without discrimination. Second, every individual is equal under the law without discrimination. Third, every individual has the right to equal protection of the law without discrimination. Fourth, every individual has the right to equal benefit of the law without discrimination. ${ }^{8}$

A review of the Canadian Bill of Rights, ${ }^{9}$ the American Constitution and international treaties will disclose the origins of $s .15(1)$. Its creators have been influenced by these sources, as well as Canadian case law.

The impact of the Canadian Bill of Rights is obvious. Section 1(b) states: ${ }^{10}$

It is hereby recognized and declared that in Canada there have existed and shall continue to exist without discrimination by reason of race, national origin, colour, religion or sex, the following human rights and fundamental freedoms, namely,

......

(b) the right of the individual to equality before the law and the protection of the law. [Emphasis added.]

Equally apparent is the American contribution. Section 1 of the fourteenth amendment provides:"

All persons born or naturalized in the United States, and subject to the jurisdiction thereof, are citizens of the United States and of the State wherein they reside. No State shall make or enforce any law which shall abridge the privileges or immunities of citizens of the United States; nor shall any State deprive any person of life, liberty, or property, without due process of law; nor deny to any person within its jurisdiction the equal protection of the laws. [Emphasis added.]

The Canadian Bill of Rights and the United States Constitution account directly for equality concepts one and three noted above, namely, equality before the law and equal protection of the law. More generally the Canadian Bill of Rights also contained a "without discrimination" clause which the drafters of $s .15$ (1) introduced in roughly the same form. There is nothing comparable in the American Bill of Rights.

International human rights instruments also have had an impact on s. 15. Article 26 of the International Covenant on Civil and Political Rights ${ }^{12}$ reads:

All persons are equal before the law and are entitled without any discrimination to the equal protection of the law. In this respect, the law shall prohibit any discrimination and guarantee to all persons equal and effective protection against discrimination on any ground such as race, colour, sex, language, religion, political or other opinion, national or social origin, property, birth or other status.

Article 7 of the Universal Declaration of Human Rights "states that "All are equal before the law and are entitled without any discrimination to equal protection of the law. All are entitled to equal protection against any discrimination in violation of this Declaration and against any incitement to such discrimination."

8. This assumes that "without discrimination" applies not to just the words in s. 15(1) beginning with "and has the right to."

9. R.S.C. 1970, App. III.

10. Id.

11. U.S. Const. amend XIV, s. 1 .

12. G.A. Res. 2200 A (XXI), 21 U.N. GAOR Supp. (No. 16) at 55-56, U.N. Doc A/6316 (1966).

13. G.A. Res. 217 A (III), U.N. Doc. A/810 (1948) at 73. 
It will be noted that the Covenant and Declaration incorporate equality concepts one and three, as well as the "no discrimination" clause. The Universal Declaration of Human Rights does not contain a list of prohibited grounds, but the International Covenant on Civil and Political Rights does, a feature of the Canadian Bill of Rights.

Equality concepts two and four are unique to the Canadian Charter of Rights and Freedoms and are attributable to Canadian case law, ${ }^{14}$ in particular, A.G. of Canada v. Lavell ${ }^{15}$ and Bliss v. A.G. of Canada ${ }^{16}$

In Canada v. Lavell, a case dealing with unequal treatment of Indian men and women, Mr. Justice Ritchie fashioned a restrictive view of equality before the law. He wrote: ${ }^{17}$

\begin{abstract}
[I]n my opinion the phrase "equally before the law" as employed in section l(b) of the Bill of Rights is to be treated as meaning equality in the administration or application of the law by the law enforcement authorities and the ordinary courts of the land. This construction is, in my view, supported by the provisions of subsections (a) to (g) of s. 2 of the Bill which clearly indicate to me that it was equality in the administration and enforcement of the law with which Parliament was concerned when it guaranteed the continued existence of "equality before the law."
\end{abstract}

This is one branch of the rule of law as expressed by Dicey in the nineteenth century. ${ }^{18}$ Earlier in his reasons, Mr. Justice Ritchie had concluded that s. 1(b) "is not effective to invoke the egalitarian concept exemplified by the 14th Amendment of the U.S. Constitution. . . " "19 (No effect was given to the phrase "protection of the law" in s. 1(b). That is more surprising than the meaning Mr. Justice Ritchie attributed to "equality before the law." ${ }^{20}$

To preclude future decision makers from adopting the same interpretation of "equality before the law" the phrase "equal under the law" was inserted into the Charter. ${ }^{21}$ It was designed to redress the problem of unequal laws and to introduce substantive as opposed to procedural standards, the latter being Mr. Justice Ritchie's concern.

Bliss v. Canada ${ }^{22}$ accounts for the presence of the phrase "equal benefit of the law." Federal unemployment insurance set different qualifying standards for pregnant women than for other unemployed men and women. Thus, though Ms. Bliss was available for work shortly after childbirth and would have been entitled to benefits under the ordinary

14. P. Hogg, Canada Act 1982 Annotated (1982) 51.

15. [1974] S.C.R. 1349.

16. [1979] I S.C.R. 183.

17. Supra n. 15 at $1366-67$.

18. Id. at 1365-66.

19. Id. at 1365 .

20. See also The Queen v. Gonzales (1962) 32 D.L.R. (2d) 290 at 296 (B.C.C.A.).

21. It was open to the Court to read s. 1(b) broader than it did. In Strauder v. West Virginia, 100 U.S. 303 at 307 (1880) Mr. Justice Strong wrote: "What is [the equal protection clause] but declaring the law in the States shall be the same for the black as for the white; that all persons, whether colored or white, shall stand equal before the laws of the States, and, in regard to the colored race, for whose protection the amendment was primarily designed, that no discrimination shall be made against them by law because of their color?"

22. Supra n. 16. 
rules had she not been pregnant, she was not eligible for unemployment insurance. Mr. Justice Ritchie rationalized this result as follows: $:^{23}$

[S.] 46 constitutes a limitation on the entitlement to benefits of a specific group of individuals and as such was part of a valid federal scheme. There is a wide difference between legislation which treats one section of the population more harshly than all others by reason of race as in the case of Regina v. Drybones, supra, and legislation providing additional benefits to one class of women, specifying the conditions which entitle a claimant to such benefits and defining a period during which no benefits are available. The one case involves the imposition of a penalty on a racial group to which other citizens are not subjected; the other involves a definition of the qualifications required for entitlement to benefits, and in my view the enforcement of the limitation provided by s. 46 does not involve denial of equality of treatment in the administration and enforcement of the law before the ordinary courts of the land as was the case in Drybones.

The presence of "equal benefit of the law" in s. 15(1) ensures that a distinction will not be made between burdens and benefits imposed by laws subject to s. 15 analysis. This concern was probably unfounded as the presence of the "equal protection" clause, an American concept, most likely made the distinction insignificant. ${ }^{24}$ In Zobel v. Williams, ${ }^{25}$ Chief Justice Burger held that "When a State distributes benefits unequally, the distinctions it makes are subject to scrutiny under the Equal Protection Clause of the Fourteenth Amendment." The Court struck down an Alaska law which distributed petroleum revenue to state residents on the basis of years of residency in Alaska.

Of the four equality concepts in s. 15(1), only the first, equality before the law, has been interpreted by the Supreme Court of Canada. This concept ensured procedural equality. It did not promote substantive fairness. That task is accomplished by the other three concepts: equal under the law; equal benefit of the law; and equal protection of the law. ${ }^{26}$

There is probably no value in considering these three concepts separately. ${ }^{27}$ Each would appear to represent the same objective and to utilize the same justification standard. "Equal under the law" and "equal benefit of the law" were meant to introduce a substantive dimension to s. 15 which "equality before the law" lacked..$^{28}$ The particular form this substantive dimension will take will not be attributable to the presence of "equal under the law" and "equal benefit of the law." It will reflect the spirit and purpose of s. 15 as a whole and the American experience interpreting the fourteenth amendment.

23. Id. at $191-92$.

24. The Constitution and the People of Canada (1969) $51-52$ (federal paper proposed recognition of the "right ... to the equal protection of the law").

25. 457 U.S. 55 at 60 (1982).

26. Re McDonald and the Queen, supra n. 3 at 764; R. v. D.I.L. (1985) 46 C.R. (3d) 172 at 178 (Ont. Dist. Ct.).

27. Contra Bayefsky, "Defining Equality Rights" in Equality Rights and the Canadian Charter of Rights and Freedoms (A. Bayefsky \& M. Eberts eds. 1985) 23; Seale, "Can the Canada Pension Plan Survive the Charter? Section 15(1) and Sex (In)Equality" (1985) 10 Queen's L.J. 441 at 465.

28. See L. Tribe, American Constitutional Law (1978) 991-1136; J. Nowak, et al., Handbook on Constitutional Law (1978) 517-688. 


\section{SECTION 15(1) QUERIES}

A. The likelihood that any legal problem will be correctly solved increases dramatically if the right questions are asked in the correct order. This process will ensure that the competing interests are disclosed and that no relevant considerations have been overlooked. Thereafter, the wisdom and experience of the decision maker determines how adverse interests are to be reconciled. This is what Professor Lederman meant when he wrote, "In this inquiry, the judges are beyond the aid of logic, because logic merely displays the many possible classifications, it does not assist in a choice between them." 29

Distribution of power problems under ss. 91 and 92 of the Constitution Act, 1867 lend themselves to the approach articulated by Professor Lederman in his writings. Does the attacked law when enforced demonstrate features that cause it to be characterized as one of the class of laws set out in s. 92? If not, the federal government has exclusive power to enact the law. If it does, does the attached law when enforced demonstrate features that cause it to be characterized as one of the class of laws set out in s.91? If not, the province has exclusive jurisdiction. If it does, then the aspects which are in competition must be evaluated and their relative importance established. Professor Lederman explained: ${ }^{30}$

When a particular rule has features of meaning relevant to both federal and provincial classes of laws, then the question must be asked, Is it better for the people that this thing be done on a national level, or on a provincial level. In other words, is the feature of the challenged law which falls within the federal class more important to the well-being of the country than that which falls within the provincial class of laws? Such considerations as the relative value of uniformity and regional diversity, the relative merits of local versus central administration, and the justice of minority claims, would have to be weighed.

The Charter, and s. 15 in particular, lends itself to logical inquiry. The questions are different than those relating to distribution of power problems. However, posing the correct questions produces the same result, disclosing the interests which contend for judicial recognition as of paramount importance.

B. Generally, with respect to all Charter problems, there are two overriding queries. First, does the suspect law violate a right or freedom set out in the Charter? If not, then the inquiry ends. If it does, is the limitation justifiable either on account of $s .1$ or the limitation set out in the section proclaiming the right or freedom? ${ }^{31}$

Further questions, the content of which changes with the right under scrutiny, must then be asked to answer each of these two basic questions. These questions are properly considered as supplementary or explanatory to or of the basic queries.

In s. 15(1) claims, there are five crucial questions. They are prompted by the fact that the thrust of s. 15(1) is this: "[A]ll persons similarly

29. W. Lederman, "Classification of Laws and the British North America Act" in The Courts and the Canadian Constitution (W. Lederman ed. 1964) 188-89.

30. Id. at 189.

31. See The Queen v. Big M. Drug Mart Ltd., supra n. 3 at 351; Reference re Public Service Employee Relations Act (1984) 35 Alta. L.R. 124 at 132 (C.A.). 
circumstanced shall be treated alike." ${ }_{32}$ Or put another way, those not similarly circumstanced should not be treated alike. To implement this objective these questions must be answered. First, is the object of the law inconsistent with s. 15 or other constitutional values? If it is, the law is of no force or effect and the inquiry is at an end. Legislation which has as its purpose a goal inconsistent with the Charter is unconstitutional. Mr. Justice Dickson, in The Queen v. Big M Drug Mart Ltd. ${ }^{33}$ stated, "While there is no authority on this point, it seems clear that Parliament cannot rely upon an ultra vires purpose under s. 1 of the Charter." For example, if a law was passed which prohibited women from becoming members of The Law Society of Alberta, its discriminatory purpose would invalidate it. ${ }^{34}$ Second, what are the characteristics of persons similarly situated with respect to the law? Third, does the impugned legislation treat all like situated the same? Or does the legislation treat those who are not alike differently? If the law treats all who are alike the same and none who are not alike the same, then the inquiry is at an end. This would be the case if provincial safety laws required all boaters, including canoeists to wear life jackets. Everyone whose safety is jeopardized by water transportation would be covered and these are the persons who are similarly circumstanced. If the law violates either of these standards, the fourth question arises, namely what is the proper characterization of the group subject to dissimilar treatment? Fifth, is the distinction one the Charter allows? What explanation will justify the unequal treatment accorded those who are alike or the equal treatment given those who are not alike? This will necessitate the application of $s .1$.

\section{Is the Law's Purpose Unconstitutional?}

Laws which strike at the heart of the Charter will in turn be dealt a fatal blow. They will be adjudged of no force or effect. ${ }^{35}$ To determine a law's purpose one must read the law. What it says is a good indication of what its purpose is. ${ }^{36}$ If this process alone is not determinative its effects should be canvassed. What are its ordinary consequences? Professor Lederman has stated: ${ }^{37}$

A rule of law expresses what should be human action or conduct in a given factual situation. We assume enforcement and observance of the rule and hence judge its meaning in terms of the consequences of the action called for. It is the effects of observance of the rule that constitute at least in part its interest, object or purpose.

32. F.S. Royster Guano Co. v. Virginia, 253 U.S. 412 at 415 (1920). See also Re McDonald and The Queen, supra n. 3 at 765; Weinstein v. Minister of Education [1985] 5 W.W.R. 724 at 738 (B.C.S.C.).

33. Supra n. 3 at 353.

34. Goesaert v. Cleary, 335 U.S. 464 (1948) (Michigan statute excluded women not wives or daughters of male owners from being bartenders).

35. See The Queen v. Big M. Drug Mart Ltd., supra n. 3 (Lord's Day Act enforcement of religious observance is unconstitutional); British Columbia \& Yukon Territory Bldg. \& Constr. Trades Council v. British Columbia, supra n. 7 at 292; N. Finkelstein, "Sections 1 and 15 of the Canadian Charter of Rights and Freedoms and the Relevance of the U.S.

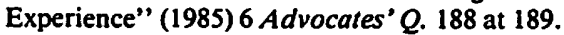

36. British Columbia \& Yukon Territory Bldg. \& Constr. Trades Council v. British Columbia, supra $\mathrm{n} .7$ at 292.

37. Supra n. 29 at 187. 
If a determination is made that the law's objective is not unconstitutional the remaining queries must be posed.

\section{What Are the Characteristics of Persons Similarly Situated?}

Once the legislative objective is known, it is possible to identify the characteristics of those whose conduct must be affected to accomplish the legislative goal. This is the group, which for purposes of the attacked law, is similarly situated. ${ }^{38} \mathrm{~A}$ simple example will show what this concept means. Suppose that a province wished to reduce the infant mortality rate and to that end passed a law which entitled pregnant women and infants to milk vouchers. By this action the legislature has identified those persons whose health will have an impact on the infant mortality rate. Accordingly, pregnant women and infants are the persons similarly situated in this fact pattern.

Isolating those who are alike is not trouble free. An American Sunday closing case confirms this. In Terry Carpenter, Inc. v. Wood ${ }^{39}$ the Nebraska Supreme Court had to decide whether a state law promoting "the health and welfare of the people of the State of Nebraska by establishing a common day of rest and recreation" was unconstitutional. The issue was a complicated one because the law imposed limitations on retail sellers and did not restrict wholesalers, manufacturers, builders or those who provide services to the community. An exemption was made for businesses employing not more than two employees.

It was open to the court to characterize those who are alike for the purpose of this law a number of ways. Was it persons who conducted retail business with two or less employees? Was it persons who conducted retail business? Was it persons who conducted business involving the sale of goods, both at the retail and wholesale level? Was it persons who conducted business engaged in commercial activities, including sales and service? Was it persons whose business activities required employees to work Sundays? This would encompass retailers, wholesalers, service industries, manufacturers, processers, to name but a few.

Obviously, each option is different and each succeeding one increases the size of the class of persons who were alike for the purposes of Nebraska's Sunday closing law. Equally obvious is the significance of the choice the court makes. If the first option was selected very few businesses could successfully complain that the law was unconstitutional. Only those retail businesses with two or less employees could complain. Thus, so long as the law treated all retailers of this size the same and did not allow some and not others to stay open, it would survive judicial review. However, if the court chose the last option, any constitutional challenge launched by any business required to close Sunday would have in it the seeds of success.

38. See generally J. Tussman \& J. tenBroek, "The Equal Protection of the Laws" (1949) 37 Calif. L. Rev. 341.

39. 177 Neb. 515,129 N.W. $2 \mathrm{~d} 475$ (1964). 
This is because the complainant would qualify as one of those businesses similarly circumstanced with respect to the law. ${ }^{40}$

One other example will illustrate how difficult it is to populate the class of similarly situated persons. In Railway Express Agency v. New York, ${ }^{4}$ a traffic regulation was under review: ${ }^{42}$

No person shall operate, or cause to be operated, in or upon any street an advertising vehicle; provided that nothing herein contained shall prevent the putting of business notices upon business delivery vehicles, so long as such vehicles are engaged in the usual business or regular work of the owner and not used merely or mainly for advertising.

This regulation was passed in response to concerns about the distractions experienced by drivers and pedestrians alike. Who then is in the group which is alike for the purposes of the traffic rule? Is it persons who own property which can be seen by those who use the streets of New York? Or is this too broad a statement of the class which is the target of New York's traffic regulation? Is the set composed of those who own vehicles which carry mainly commercial messages? Is this formulation too narrow? Does it not omit persons whose conduct has to be altered if users of New York's streets are not to be distracted?

Care has to be taken to utilize a level of abstraction which accurately reflects the nature of the problem under legislative consideration. By narrowing the focus unduly the analyst may omit a crucial part of the problem and cause the inquiry to be brought to an abrupt and premature end.$^{43}$ This would be the result if it was determined that a complainant is not a member of the group who is similarly situated with respect to the purpose of the law. A s. 15 complaint is dependent on a finding that likes have been treated differently. For this reason, courts must utilize a level of abstraction comparable to that incorporated in s. 15(1). In other words, because s. 15(1) employs a broad focus, so should the courts. By doing so, the courts will insure that important constitutional issues are not short circuited and disposed of on the basis that the complainant could not show membership in the class of persons who are alike.

At the same time, courts should be free to reach this conclusion where circumstances warrant it. ${ }^{44}$ If the complainant cannot show that he is a member of the group consisting of those who are alike, it makes no sense to

40. The court rejected the narrower formulations. Mr. Justice Spencer wrote: "With respect to the exempted retailers, the discrimination is even more obvious. If the purpose of the act is to promote the health and welfare of the people of the State of Nebraska, why should twoemployee retailers be exempt? For that matter, why should everyone but retailers be exempt?", id. at 480 (N.W.).

41. 336 U.S. 106 (1949).

42. Id. at 107-08.

43. At each level of abstraction, the set becomes larger. For example, belladonna is a deadly poison but any of the following descriptions might be appropriate: (1) poison capable of fatal results if improperly used, (b) poison, (c) obviously and necessarily dangerous substance and (d) substance potentially dangerous if improperly labelled. A cooking utensil described as "microwave fit" would be covered by (d) if it was not suitable for use in a microwave. At the same time, it would not be subsumed under (a). This shows why it is important to select the appropriate degree of abstraction.

44. See R. v. Swain (1986) 13 O.A.C. 161 at $187-88$ (C.A.) (insane acquittee and person acquitted simpliciter are not similarly situated); Cabre Exploration Ltd. v. Arndt, unreported, 8 April 1986, No. 850319134 (Alta. Q.B.) (owner and operator under the Surface Rights Act are not similarly situated). 
conduct a s. 1 inquiry, with its attendant consequences for the defender of the legislation. Suppose an employed person alleged that the unemployment insurance scheme was inconsistent with s. 15(1) because benefits were not given to those with full-time employment. Is it not clear that the appropriate level of abstraction is unemployed persons? Why should the unemployment insurance commission be asked to explain why benefits are not given to persons with full-time employment?

\section{Does the Law Accord Similar Treatment?}

Once it has been decided what the characteristics of persons similarly situated are, using the purpose of the law as a benchmark, a finding must be made as to whether the law accords persons with these traits similar or substantially similar treatment. This involves a review of the means by which the law's purpose is pursued. ${ }^{45}$ Once the law's method is understood it can be adjudged whether those who are alike are in fact treated the same. ${ }^{46}$

Most of the time it is relatively easy to ascertain whether the law bestows similar benefits or makes similar demands on those who are similarly circumstanced. One simply asks whether the legislation treats members of the group identified by the second interrogatory, what are the characteristics of persons similarly situated, the same under circumstances regulated by the law subject to constitutional assault.

Sunday closing laws again serve as good examples. In Nation v. Giant Drug Co. ${ }^{47}$ the ordinance attacked required the closing of certain businesses on Sunday. Exceptions were made by reference to type of business and product sold. A grocery store could on Sunday sell bread but a bakery could not. This inequity, along with others, led the court to conclude that likes were not treated alike.

$\operatorname{Re~Schmitz}{ }^{48}$ also shows how this third question may be answered. The Canadian Citizenship Act ${ }^{49}$ was under review. By its provisions an alien female who married a Canadian citizen was eligible for citizenship after residing in Canada for a year. A male applicant or a female not married to a Canadian male had to wait a much longer time. Section 10(1) of the Canadian Citizenship Act stated:

The Minister may, in his discretion, grant a certificate of citizenship to any person who is not a Canadian citizen and who makes application for that purpose and satisfies the Court that

(a) he has attained the age of twenty-one years, or he is the spouse of and resides in Canada with a Canadian citizen;

(b) he has resided in Canada for at least twelve of the eighteen months immediately preceding the date of his application;

45. See generally J. Tussman and J. tenBroek, supra n. 38.

46. Minor discrepancies do not warrant judicial intervention. State v. Target Stores, Inc, 156 N.W. 2 d 908 (Minn. 1968). Major deviations do. In most instances laws bestow the same benefits and make the same demands on those who are alike.

47. 396 P. 2d 431 (Wyo. 1964).

48. (1972) 31 D.L.R. (3d) 117 (Citizenship App. Ct.).

49. R.S.C. 1970 , c. C-19. 
(c) the applicant has

(i) been lawfully admitted to Canada for permanent residence and has, since such admission, resided in Canada for at least five of the eight years immediately preceeding the date of application, but for the purpose of this subparagraph, each full year of residence in Canada by the applicant prior to his lawful admission to Canada for permanent residence is deemed to be one-half year of residence in Canada within the eight year period referred to in this subparagraph,

(ii) served outside of Canada in the armed forces of Canada in a war in which Canada was or is engaged or in connection with any action taken by Canada under the United Nations Charter, the North Atlantic Treaty or other similar instrument for collective defence that may be entered into by Canada,

(iii) been lawfully admitted to Canada for permanent residence and is the wife of a Canadian citizen, or

(iv) had a place of domicile in Canada for at least twenty years immediately before the 1st day of January 1947 and was not, on that date, under order of deportation.

It is not difficult to extract the legislative purpose. In s. 10 Parliament sets out to establish criteria which must be met before a certificate of citizenship will be granted. Generally, only those who can demonstrate a substantial commitment to and connection with Canada or Canadians will be considered for citizenship. Those like situated for purposes of this case are persons: (a) who are not Canadian citizens (b) have a substantial connection to or with Canada or Canadians, and (c) have made an application for a certificate of citizenship.

Having reached this conclusion it is obvious that a member of this group, namely a person who has met the criteria set out in s. 10(1)(a)(b), but who is also female and married to a Canadian citizen enjoys an advantage not shared by male applicants, whether married or not, and female applicants, who are either unmarried or if married whose spouse is not a Canadian citizen. The female applicant with a Canadian husband is eligible for a certificate of citizenship at an earlier time than the male applicant, regardless of his marital status, and the female applicant who is not married to a Canadian citizen.

\section{What Are the Characteristics of the Subgroup Accorded Dissimilar Treatment?}

After a conclusion is reached that members of the like situated group are not accorded the same benefits or do not bear the same burdens, the subgroups formed by the unequal treatment must be identified. This is the task just completed in the Schmitz case. Those who are treated more favorably than others in the group were alien females married to Canadian males. As a result males, without reference to their marital status, and female aliens who were not married to Canadian men, were subjected to harsher treatment by the Canada Citizenship Act.

It is important to identify this subgroup and attach where possible appropriate descriptions of the characteristics of the subgroup utilizing the same level of abstraction as s. 15 employs in its enumerated prohibited grounds of discrimination. For example, if a law prohibited citizens of Libya from applying for Canadian citizenship the appropriate description would be "national origin". This allows one to proceed to the next question. 


\section{5.(a) Is the Classification One the Charter Allows?}

As noted above, Charter problems involve two overriding inquiries. Does the subject law violate a right or freedom set out in the Charter and, if it does, is the violation justifiable in terms of $s .1$ or some other section? ${ }^{30}$ Answers to the first four questions posed above determine whether a Charter right or freedom has been violated..$^{\text {s1 }}$ The four questions are: 1 . Is the object of the law unconstitutional? 2. What are the characteristics of persons similarly situated with respect to the law? 3 . Does the attacked law treat all who are similarly situated the same? 4 . What are the characteristics of the group subject to dissimilar treatment? A conclusion that the law does not treat all who have the characteristics of the like situated group the same means that a Charter right or freedom may have been violated. This is so whether or not the classification utilized is one of the nine ${ }^{52}$ listed in s. 15. ${ }^{33} \mathrm{Mr}$. Justice Spencer has opined that s. 15(1) is "open-ended and [may extend] . . . to other unenumerated freedoms which may be recognized by the courts in the future." $\$ 4$

Re Schmitz shows how this problem could arise. The Canadian Citizenship Act discriminated both on the basis of sex and marital status. To be precise, discrimination was not solely on the ground of marital status. If a female candidate was married, but not to a Canadian, she did not enjoy the reduced waiting period. Thus, the basis for classification was marriage to a male Canadian citizen. Because sex is one of the nine enumerated grounded in s. 15(1), there is a apparent conflict with s. 15(1). Just because marital status is not listed in s. 15(1) would not preclude a court from hearing an allegation that under the circumstances marital status is an unconstitutional classification. For example, in statements of claim issued in Alberta plaintiffs have alleged that they have been discriminated against because they are large retailers..$^{55}$ This is not one of the expressly prohibited grounds in s. 15(1). Nonetheless, an interlocutory injunction was granted enjoining The City of Red Deer from enforcing its Sunday closing by-law. ${ }^{56}$

The next example shows why it should not be fatal if the challenged classification is not enumerated in s. 15(1). A classification system might offend a principle contained in a Charter provision other than s. 15(1). There is no reason to believe that the location of the principle in the Charter

50. British Columbia \& Yukon Territory Bldg. \& Constr. Trades Council v. British Columbia, supra n. 7 at 285.

51. Contra Smith, Kline \& French Laboratories Ltd. v. A.G. of Canada (1985) 7 C.P.R. (3d) 145 at $192-93$ (F.C.T.D.).

52. (1) race, (2) national origin, (3) ethnic origin, (4) colour, (5) religion, (6) sex, (7) age, (8) mental disability and (9) physical disability.

53. P. Hogg, supra n. 14 at 51.

54. British Columbia \& Yukon Territory Bldg. \& Constr. Trades Council v. British Columbia, supra n. 7 at 287-88. See also Smith, Kline \& French Laboratories Ltd. v. A.G. of Canada, supra n. 51 at 193; Kask v. Shimizu, supran. 2 at 10; Paquette v. The Queen [1986] 3 W.W.R. 232 (Alta. Q.B.); R. v. Doucette, supra n. 7 at 21.

55. London Drugs Ltd. v. Red Deer (Q.B. No. 8510-02601) \& The Brick Warehouse Ltd. v. The City of Fort McMurray, (Q.B. No. 8513-001206).

56. London Drugs Ltd. v. Red Deer[1986] 3 W.W.R. 326 (Alta. Q.B.). 
is more significant than the importance of the principle. ${ }^{57}$ Suppose Alberta imposed a surtax on residents who had resided in a province other than Alberta within the last two years. Such a clumsy measure might discourage migration to Alberta, or it might be thought that newcomers should pay a disproportionate share of the public expenditures recent large population increases prompted. In any event, resident Albertans were the group similarly situated and, within this group, a subgroup was created, namely, newcomers to Alberta. It might well be that Alberta cannot discriminate against newcomers in this way. Section 6 of the Charter would suggest that discrimination on the basis of prior residence is not a permitted legislative tool. Section 6(2) reads: "Every citizen of Canada and every person who has the status of a permanent resident of Canada has the right (a) to move to and take up residence in any province; and (b) to pursue the gaining of a livelihood in any province."

What is the significance of the enumerated grounds of discrimination? It is best understood if the potential bases for classification are divided into three sets. The first consists of classifications which are enumerated in $\mathbf{s .}$ 15. In the second set are classifications not enumerated in s. 15 but offensive to other Charter or constitutional principles. The third set encompasses all other classifications. If a classification falls within the first or second sets the likelihood that it will withstand judicial review is less than if the classification came from the third set. This theme will be developed later.

(b)(i) Before inquiring further as to whether a particular classification is one the Charter allows, it will be useful to summarize what has been submitted and to disclose two assumptions which have been made. To summarize: one, the legislative object must not be proscribed in the Charter. Two, s. 15(1) ensures that "all person similarly circumstanced shall be treated alike" ${ }^{\prime s 8}$ and that persons who are differently situated will not be treated alike. Three, the characteristics of persons who are similarly circumstanced must be identified. Four, it must be ascertained whether the impugned legislation treats those who are alike the same. Five, if unequal treatment exists, subgroups must be recognized and a group characteristic formulated. Six, the likelihood that discrimination against those with the characteristics of the subgroup is unconstitutional increases if the classification is listed in s. 15(1) or offends a principle of constitutional law.

(ii) Some courts have held and some observers have suggested that corporations cannot invoke s. 15(1). ${ }^{39}$ This is because the word "individual" is used to describe those who are entitled to s. 15(1) rights. If this suggestion attracted general judicial support it would be regrettable. Such an interpretation would mean that the very provision which proclaims

57. Kask v. Shimizu, supra n. 2 at 18-19; See Black v. Law Society of Alberta (1984) 57 A.R. 1 at 23 (Q.B.) (members of Law Society who belong to more than one partnership and have partners who reside outside Alberta are singled out for special treatment).

58. F.S. Royster Guano Co., supra n. 32 at 415.

59. Smith, Kline \& French Laboratories Ltd. v. A. G. of Canada, supra n. 51 at 191-92; P. Hogg, Constitutional Law of Canada (2nd ed. 1985) 667 \& 798; P. Hogg, Canada Act Annotated 1982, supra n. 14 at 50; W. Moull, "Business Law Implications of the Canadian Charter of Rights and Freedoms" (1984) 8 Can. Bus. L.J. 449 at 452-53. 
equality as a cornerstone constitutional principle irrationally relegates the dominant form of business and charitable organization to an inferior position and brings to life the best forgotten Edwards v. Canada ${ }^{60}$ the case which held women not to be "persons" within s. 24 of the Constitution Act, 1867. Unless compelled to do so, courts should not read "individual" to exclude corporations.

Apart from the fact that there is no rational explanation for depriving corporations of the protection s. 15(1) affords, there are many reasons why "individual" includes corporations. ${ }^{61}$ One, the charter is to be given a broad and liberal interpretation. Two, the federal Interpretation Act $^{62}$ indicates that " "person' or any word or expression descriptive of a person" includes corporations. Three, the French text, which is equally authoritative by virtue of s. 57 of the Charter, uses the words "personne" and "tous", which according to Petit Larousse ${ }^{63}$ includes corporations. Four, the English and French versions of ss. 15 and 24 read together, conclusively establish that "individual" does not exclude corporations. As Mr. Chipeur explained, ${ }^{64}$

If the term "personne" in s. $15(1)$ is defined to exclude corporations then it would logically follow that the term "personne" in s. $24(1)$ should also be defined to exclude corporations. ... .

Canadian courts have held that . . . "personne" in s. 24 "includes a corporation. . . ."

Five, English and American case law have held that "individual" includes corporations. ${ }^{65} \mathrm{Six}$, undesirable anomalies would result. For example, a sole proprietor could invoke s. 15 in attacking suspect hours of business laws but a corporation could not. To allow this would be illogical. Seven, Mr. Chipeur is correct when he concluded:66

The inclusion of corporations under the protective umbrella of the Charter will benefit all who may find their rights infringed by government. Because constitutional litigation is expensive, many people will find it too costly to raise Charter issues in the courts, whereas corporations will, with their greater financial resources, have the funds to finance Charter litigation. The rights established and defined in such litigation may be enjoyed by all individuals, both natural and corporate.

(iii) What does "without discrimination" mean? The standard dictionaries and case law provide the answer. The Oxford Universal Dictionary on Historical Principles ${ }^{67}$ states that "discriminate" means " [t]o make or constitute a difference in or between; to differentiate." Much the same definition is offered by Webster's Third New International Dictionary:68 "Discrimination . . . la: the act or an instance of discriminating: as (1) the

60. [1928] S.C.R. 276.

61. See Chipeur, "Section 15 of the Charter Protects People and Corporations Equally" (1986) 11 Can. Bus. L.J. 304.

62. R.S.C. 1970, c. I-23, s. 28 . This source is persuasive, not determinative.

63. Librairie Larousse, Paris (1959).

64. Supra n. 61 at 314.

65. Great Northern Railway v. Great Central Railway (1899) 10 Ry. \& Can. Tr. Cas. 266 at 275; State v. Bell Telephone Co., 36 Ohio St. 296 at 310 (S.C. 1880). Contra The Queen v. Colgate Palmolive Ltd. (1971) 8 C.C.C. (2d) 40 at 43 (Ont. Co. Ct.); New Brunswick Broadcasting Co. v. Canadian Radio-Television \& Telecommunications Commission (1984) 55 N.R. 143 (Fed. C.A.).

66. Supra n. 61 at 315.

67. (3rd ed. 1955).

68. (1981). 
making or perceiving of distinction or difference ... 4: the act, practice, or an instance of discriminating categorically rather than individually ... as a: the according of differential treatment to persons of an alien race or religion." That same source states that "discriminate" means "to make a distinction."

There is nothing in the ordinary meaning of "discrimination" which obliges one to conclude that it is a purposive act. To do so would emasculate s. 15. It would also be inconsistent with the Supreme Court's direction to read the Charter broadly, consistent with its status as the supreme law of the land. ${ }^{69}$ Further, it would be inconsistent with the Supreme Court of Canada's decision in Ontario Human Rights Commission v. Simpson-Sears Ltd. ${ }^{70}$ The Court considered the meaning of "discriminate" in s. 4(1)(g) of the Ontario Human Rights Code," which read:

4. - (1) No person shall

(g) discriminate against any employee with regard to any term or condition of employment,

because of race, creed, colour, age, sex, marital status, nationality, ancestry, or place of origin of such person or employee.

Mr. Justice McIntyre held that unlawful discrimination can be established in the absence of an intent to impose unequal burdens on an individual. He wrote: ${ }^{22}$

\begin{abstract}
It is the result or the effect of the action complained of which is significant. If it does, in fact, cause discrimination; if its effect is to impose on one person or group of persons obligations, penalties, or restrictive conditions not imposed on other members of the community, it is discriminatory.
\end{abstract}

At a later stage in his reasons he explained his understanding of the concept:" "An employment rule honestly made for sound economic or business reasons, equally applicable to all to which it is intended to apply, may yet be discriminatory if it affects a person or group of persons differently from others to whom it may apply."

This is the approach which should be and has been adopted by the courts when applying s. $15(1) .^{74}$ The Charter places limits on lawmakers' powers and the limitations lawmakers labor under should be every bit as demanding as those that private decision makers face when complying with the dictates of provincial human rights legislation. If the Supreme Court of Canada holds Simpson-Sears Limited accountable for the results of its actions, surely nothing less should be expected of the government. ${ }^{75}$

69. The Queen v. Big M. Drug Mart Ltd., supra n. 3 at 342; Kask v. Shimizu, supra n. 2 at 9.

70. [1985] 2 S.C.R. 536 .

71. R.S.O. 1980 , c. 340 .

72. Supra n. 70 at 547.

73. Id. at 551. See also Ontario Human Rights Commission v. Borough of Etobicoke [1982] 1 S.C.R. 202 at 209; A.G. of Alberta v. Gares (1976) 67 D.L.R. (3d) 635 at 695 (Alta. S.C.T.D.); Osborne v. Inco. Lid. [1984] 5 W.W.R. 228 at 238 (Man. Q.B.); Rocca Group Ltd. v. Muise (1979) 102 D.L.R. (3d) 529 at 533 (P.E.I. S.C.); Canadian Odeon Theatres Ltd. v. Saskatchewan Human Rights Commission [1985] 3 W.W.R. 717 at 740 (Sask. C.A.).

74. Kask v. Shimizu, supran. 2 at 9; British Columbia \& Yukon Territory Bldg. \& Constr. Trades Council v. British Columbia, supra n. 7 at 292.

75. See The Queen v. Big M Drug Mart, supra n. 3 at 331. 
(c) A finding that a s. 15(1) value has been infringed triggers the next stage of the inquiry, is the infringement justifiable. Sometimes the section which declares the right contains a limitation provision and that is where the justification analysis commences. Section 12 of the Charter is a good example: "Everyone has the right not to be subjected to any cruel and unusual treatment or punishment." "16 As s. 15(1) contains no limitation provision the only limitations will be found in $\mathrm{s} .1 .^{77}$

Section 1 of the Charter states that the rights and freedoms "set out in [the Charter] are subject only to such reasonable limits prescribed by law as can be demonstrably justified in a free and democratic society." This section prompts three observations. First, the rights and freedoms the Charter declares are not absolute. ${ }^{78}$ Second, if limits are to be recognized they must be "demonstrably justified in a free and democratic society." Third, the s. 1 proponent bears the burden of justifying the ostensible breach of a Charter right or freedom. ${ }^{79}$ This burden is one that should not be easily discharged and Courts must be vigilant to ensure that important freedoms are not "whittled away to such an extent that [they] would become a mere withered branch instead of the sturdy oak [they] should be in a democratic country." appropriate. ${ }^{81}$ There is no presumption of constitutionality in the Charter. ${ }^{82}$

Because s. 1 is relevant in s. 15 Charter problems, with the possible exception of sex discrimination issues, it follows that the $s .1$ proponent will have to justify the classification scheme. The $s .1$ proponent will be the litigant attempting to justify the apparent breach of a s. 15(1) right.

\section{STANDARD OF COMPLIANCE}

What standard will be adopted to measure compliance with s. 1 with respect to s. 15(1) rights? How will a court know when a limit is reasonable in a free and democratic society? What have the courts done in s. 15(1) cases which have been decided to date? How did the courts solve equality cases under the Canadian Bill of Rights?

76. See Moore v. The Queen (1984) 45 O.R. (2d) 3 at 10 (H.C.J.) (s. 1 of the Charter not relevant). Contra Law Society of Upper Canada v. Skapinker (1984) 9 D.L.R. (4th) 161 at 181 (S.C.C.); Basile v. A.G. of Nova Scotia (1984) 11 D.L.R. (4th) 219 (N.S.S.C. App. Div.); P. Hogs, Canada Act 1982 Annotated, supra n. 14 at 25.

77. See Seale, supra n. 27 at 469.

78. The Queen v. Oakes, supra n. 2 at 126; Reference re Public Service Employee Relations Act, supra n. 31 at 131.

79. Hunter v. Southam Inc. [1984] 2 S.C.R. 145; The Queen v. Big M. Drug Mart [1984] 1 W.W.R. 625 at 647 (Alta. C.A.).

80. R. v. Naish [1950] I W.W.R. 987 at 996 (Sask. Mag. Ct.).

81. The Queen v. Oakes, supra n. 2 at 127; Singh v. Minister of Employment \& Immigration [1985] 1 S.C.R. 177 at 218.

82. Southam Inc. v. The Queen (No. I) (1983) 146 D.L.R. (3d) 408 at 420 (Ont. C.A.). Contra Smith, Kline \& French Laboratories Ltd. v. A.G. of Canada, supra n. 51 at 193-94. 
[VOL. XXIV, NO. 3

\section{A. CANADIAN BILL OF RIGHTS}

1. The Canadian experience with s. 1(b) of the Canadian Bill of Rights, with one exception, is not instructive. ${ }^{83}$ MacKay v. The Queen ${ }^{84}$ is the exception. Mr. Justice McIntyre's opinion is particularly noteworthy. At issue in MacKay was "whether the provisions of the National Defence Act which authorize the trial by a service tribunal of military personnel charged with criminal offences committed in Canada contrary to the Narcotic Control Act or the Criminal Code are inoperable by reason of the Canadian Bill of Rights." 85 A member of the Canadian armed forces was convicted of possession of and trafficking in a narcotic contrary to the Narcotics Control Act ${ }^{86}$ and the National Defence Act. ${ }^{87}$ These offences occurred in army barracks.

The equality issue arises because all persons charged under the Narcotics Control Act are not tried by service tribunals. Only service personnel are and this is often contrary to their interests. The military system does not have the procedural safeguards built into the civil system. Bail is almost non-existent and there are no preliminary hearings. There are other differences as well. ${ }^{88}$

Mr. Justice McIntyre acknowledged that classification was an essential lawmaking tool ${ }^{89} \mathrm{He}$ was also cognizant of the military's special needs, writing: "It seems abundantly clear to me that the emergence of a body of military law with its judicial tribunals has been made necessary because of the peculiar problems which face the military in the performance of its varied tasks. ${ }^{\prime 90}$ Matters such as discipline come immediately to mind. Mr. Justice McIntyre was not convinced that service tribunals needed jurisdiction over all offences services personnel committed to maintain suitable levels of discipline. However, he was satisfied that it should have jurisdiction if the offence "is so connected with the service in its nature, and in the circumstances of its commission, that it would tend to affect the general standard of discipline and efficiency of the service."91

The facts showed the significant interest the services had in this case. All the offences occurred in army barracks. Had the connection been substantially diminished the appeal probably would have succeeded. $\mathrm{Mr}$. Justice McIntyre explained it as follows: ${ }^{92}$

83. Bliss v. A.G. of Canada, supra n. 16. (discrimination against pregnant women approved); A.G. of Canada v. Canard [1976] 1 S.C.R. 170 (discrimination against potential administrators because of status as Indians approved); The Queen v. Burnshine [1975] 1 S.C.R. 693 (discrimination on basis of provincial residence approved); A.G. of Canada v. Lavell, supra n. 15 (discrimination against Indian women approved); Brar v. Minister of Employment \& Immigration (1985) 60 N.R. 344 (Fed. C.A.) (discrimination against landed immigrants approved). See Seale, supra n. 27 at 454.

84. Supran. 7.

85. Id. at 401 .

86. R.S.C. 1970 , c. N-1.

87. R.S.C. 1970 , c. N-4.

88. MacKay v. The Queen, supra n. 7 at 409.

89. Id. at 406.

90. Id. at 407.

91. Id. at 410.

92. Id. at 408 . 
The needs of the military must be met but the departure from the concept of equality before the law must not be greater than is necessary for those needs. The principle which should be maintained is that the rights of the serviceman at civil law should be affected as little as possible considering the requirements of military discipline and the efficiency of the service. [Emphasis added.]

This passage reveals Mr. Justice McIntyre's conviction that fundamental rights are important enough to insist that their integrity be preserved whenever possible.

The same theme surfaces in these earlier passages in his reasons: ${ }^{93}$

The question which must be resolved in each case is whether such inequality as may be created by legislation affecting a special class - here the military - is arbitrary, capricious or unnecessary, or whether it is rationally based and acceptable as a necessary variation from the general principle of universal application of law to meet special conditions and to attain a necessary and desirable social objective. . . .

I would be of the opinion, however, that as a minimum it would be necessary to inquire whether any inequality has been created for a valid federal constitutional objective, whether it has been created rationally in the sense that it is not arbitrary or capricious and not based upon any ulterior motive or motives of fensive to the provisions of the Canadian Bill of Rights, and whether it is a necessary departure from the general principle of universal application of the law for the attainment of some necessary and desirable social objective.

To summarize, Mr. Justice McIntyre's test of constitutional compliance is twofold. First, is the legislative objective constitutionally permissible? For example, the state could not make a cash grant to all Catholics. This would be inconsistent with s. 2(a) of the Charter protecting freedom of religion and conscience and s. 15(1) promoting equality. ${ }^{94}$ Although it is not clear, Mr. Justice McIntyre also seemed to require that the objective be "necessary and desirable." Second, is the classification which created the inequality necessary to accomplish a goal which passes the first test? If it is arbitrary or capricious it obviously falls short of the mark. Presumably, even if it is not arbitrary and capricious, it may fall short of the mark if it is not "a necessary departure from the general principle of universal application...."

This insistence that the lawmaker adopt the least invasive means makes sense. It complies with the spirit of the Charter and comports with the $s .1$ guarantees of rights and freedoms. It is also reflects the view expressed by the highest courts in Canada and the United States that lawmakers must evaluate different options available and select the one that does the least damage to constitutionally protected rights. Mr. Justice Dickson has written that "[t]he court may wish to ask whether the means adopted to achieve the end sought do so by impairing as little as possible the right or freedom in question." ${ }^{96}$ In Sherbert $v$. Verner, ${ }^{97}$ a South Carolina statute prevented a Seventh-day Adventist from recovering unemployment benefits because she refused to work on Saturday, her sabbath. The state argued that it would be unable to police religious objections and that false claims would dilute the fund. However there was no evidence to substanti-

93. Id. at $406 \& 407$.

94. The Queen v. Big M Drug Mart, supra n. 3 at 350.

95. MacKay v. The Queen, supra n. 7 at 407.

96. The Que?n v. Big M. Drug Mart, supra n. 3 at 352. See also The Queen v. Bryant (1984) 6 O.A.C. 118 at 123 (C.A.).

97. 374 U.S. 398 (1963). 
ate these fears. Mr. Justice Brennan said, "[E]ven if the possibility of spurious claims did threaten to dilute the fund and disrupt the scheduling of work, it would plainly be incumbent upon the appellees to demonstrate that no alternative forms of regulation would combat such abuses without infringing First Amendment rights."

Mr. Justice McIntyre's approach stands as a warning to lawmakers that they must exercise their jurisdiction intelligently and with sensitivity. This is because legislation, as it becomes less precise, affects persons whose conduct will not decrease or increase the likelihood the legislative objective will be attained. To so burden or affect these persons is unfair and unwise. It encourages disrespect for the law as an instrument of social ordering.

The Queen v. Drybones ${ }^{9}$ is the best known Canadian Bill of Rights case, but it is not a torch which will light up dark Charter trails. In this case the correct answer struck the court as being so apparent that an extensive analysis of "equality before the law" was not required.

2. Are there any reasons why precedents interpreting s. 1(b) of the Canadian Bill of Rights should not be considered? In a word, no. Nonetheless, it must be kept in mind that the Bill of Rights "is a statute and no more, having at most a quasi-constitutional nature" ${ }^{100}$ and is not the supreme law of the land, as the Charter is. Thus, restrictive readings of the Canadian Bill of Rights must be assessed in light of the status of the Bill of Rights and the judicial reception accorded it. ${ }^{101}$ Expansive interpretations warrant serious study for that is the interpretive approach the Charter favors. Judge Jones held that "the Charter . . . should . . . be given a fuller, broader, more ample interpretation and application [than the Bill of Rights]."

\section{B. CANADIAN CHARTER OF RIGHTS AND FREEDOMS}

There are not many s. 15(1) cases which have been decided. ${ }^{103}$ The explanation is straightforward. Section 15(1) did not come into effect until

98. Id. at 407 .

99. [1970] S.C.R. 282.

100. R. v. W. H. Smith [1983] 5 W.W.R. 235 at 256 (Alta. Prov. Ct.). See MacBain v. Canadian Human Rights Commission (1985) 62 N.R. 117 at 129 (Fed. C.A.); The Queen v. Big M Drug Mart Ltd., supra n. 79 at 646-47 (Alta. C.A.).

101. The Queen v. Therens [1985] I S.C.R. 613 at 638-39 (S.C.C.); Smith, Kline \& French Laboratories Ltd. v. A.G. of Canada, supra n. 51 at 194.

102. R. v. W.H. Smith, supra n. 100 at 256. See also The Queen v. Big M Drug Mart Ltd., supran. 3 at 342-44; Jones v. A.G. of British Columbia (1985) 63 B.C.L.R. 137 at 140 (S.C.).

103. See Western Surety Co. v. Elk Valley Logging Ltd. (1985) 23 D.L.R. (4th) 464 (B.C.S.C.) (right to join Alberta as third party did not deny defendant s. 15(1) protection); Surrey Credit Union v. Mendonca, unreported, 6 November 1985, New Westminster Registry, No. A851584 (B.C.S.C.) (allegation of unlawful discrimination under federal Interest Act dismissed); Baker v. Association of Professional Engineers of the Province of British Columbia, unreported, 23 September 1985, Vancouver Registry, No. A852089 (B.C.S.C.) (allegation of unlawful discrimination under Engineers Act dismissed); Continental Distributors Ltd. v. Corporation of the Township of Richmond, unreported, 13 June 1985, Vancouver Registry, No. A850915 (B.C.S.C.) (allegation of unlawful discrimination under Municipal Act dismissed); See also Black v. Law Society of Alberta (1985) 38 Alta. L.R. (2d) 109 (C.A.) (leave to amend statement of claim to allow Court of Appeal to hear s. 15 claim not granted). 
April 17, 1985. Civil litigation takes time to mature, and while there are more criminal decisions than civil, there are not many criminal cases. ${ }^{104}$

There are several s. 15(1) Charter cases which are important. Of these, Kask v. Chimizu, ${ }^{105}$ a decision of the Court of Queen's Bench of Alberta, stands out. It does so for a number of reasons. Before cataloguing these, the nature of the issue involved should be briefly stated. The plaintiff was a nonresident of Alberta and the defendants applied for orders that she post security for costs. She successfully opposed this application on the ground that Rule 593(1)(a) of the Alberta Rules of Court was inconsistent with s. 15(1) of the Charter. Turning now to the reasons why Kask v. Shimizu represents a significant contribution to the development of s. 15(1) law: first, it reflects the purposive approach to the Charter which Mr. Justice Dickson approved in The Queen v. Big M Drug Mart ${ }^{106}$ and The Queen v. Oakes. ${ }^{107}$ Without a keen appreciation of why a Charter provision exists it is difficult to sketch in its constitutional contours. For example, a crucial part of Mr. Justice Dickson's reasons for judgment in Big M Drug Mart was entitled, "The Purpose of Protecting Freedom of Conscience and Religion." ${ }^{108}$ Second, Mr. Justice McDonald accurately characterizes the benefits of treating those who are alike the same. He wrote: ${ }^{109}$

1. When an individual is and feels equal before and under the law to other individuals, and has the protection and benefit of the law equal to that enjoyed by other individuals, he feels that his inherent dignity is respected by the social order and he, therefore, feels a higher degree of self-worth and is more likely to be a useful and contributing member of social and political institutions which enhance the participation of individuals and groups in our society.

2. When an individual is not discriminated against, particularly by government and those exercising the powers of government, on the ground of his cultural background or his being a member of a group, he feels that society respects him despite his being of a different culture or a member of a different group in comparison with others, particularly with those who exercise majoritarian or significant power. This, in turn, will tend to increase the likelihood of his having faith in social and political institutions which enhance the participation of individuals and groups in society.

In each case, as well, the sense of fair play, equality of treatment and opportunity which the individual will entertain will be likely to enhance his sense that Canada is a country in which, because it is free, he can plan his and his family's vocational and personal development, knowing with confidence that the state and those who exercise the powers of the state will obstruct his hopes and expectations only on grounds that are unrelated to inequality of treatment by the law or discrimination on the ground of some characteristic he possesses.

In each case, it is not only the individual who is directly involved, whose participation in society will be enhanced; if the individual is a member of a group sharing his characteristics, then other members of that group who become aware of the equality of treatment or the respect which he is accorded by society will share his sense that Canadian society will treat other members of the group similarly, and this will tend to increase their faith in social and political institutions which enhance the participation of individuals and

104. See The Queen v. Killen (1985) 24 C.C.C. (3d) 40 (N.S. S.C. App. Div.); R. v. Swain, supran. 44; The Queen v. Morgentaler (1985) 11 O.A.C. 81 at 111 (C.A.); Jones v. British Columbia, supra n. 102; R. v. Doucette, supra n. 7; R. v. D.I.L., supra n. 26; R. v. Hamilton (1985) 34 M.V.R. 185 (Ont. Prov. Ct.); R. v. G.M. (1985) 24 C.C.C. (3d) 288 (Ont. Prov. Ct. Fam. Div.); R. v. Drybones (1985) 23 C.C.C. (3d) 457 (N.W.T. S.C.).

105. Supra n. 2.

106. Supra n. 3 at 344.

107. Supran. 2 at 104.

108. Supra n. 3 at 344.

109. Kask v. Shimizu, supra n. 2 at 6-8. 
groups in society. Moreover, other members of the group will share the individual's confidence that the freedom of our society will, as said in the preceding paragraph, ensure that family and vocational development will not be obstructed by the state on the grounds mentioned.

Third, Mr. Justice McDonald rejected the notion that s. 15(1) dealt with purposive discrimination and not other types of discrimination. He wrote, "What matters is the effective nature and scope of the impugned legal rule in light of the provisions of the Charter, not the intent of the legislature in adopting the legal rule. . . "'10 Fourth, the Kask case explicitly recognized that the list of enumerated classification grounds is not an exhaustive statement of unconstitutional classifications."'I In the same vein, $\mathrm{Mr}$. Justice McDonald disagreed with the view that discrimination on the basis of enumerated and non-enumerated grounds invoked different standards of review. ${ }^{12}$ Fifth, the judge held that s. 15(1) does not make suspect all types of legislative classifications: ${ }^{113}$
The "discrimination" which is the target of s. 15(1) is discrimination by the state and those who exercise the powers of the state which would undermine the "essential" or "underlying" values of a free and democratic society. All of the enumerated forms of discrimination are kinds of conduct which, if practised by the state, would inhibit the sense of those who are discriminated against that Canadian society is not free or democratic as far as they are concerned and, as stated earlier, such persons are likely not to have faith in social and political institutions which enhance the participation of individuals and groups in society, or to have confidence that they can freely and without obstruction by the state pursue their and his families hopes and expectations of vocational and personal development. These are at least some of the "underlying values" which are represented by genuine freedom and democracy. When we focus on some non- enumerated grounds of discrimination, the hallmark by which a statute or administrative conduct must be judged when it is alleged that it violates the rights of an individual to the equal protection and equal benefit of the law without discrimination must be whether discrimination by the state on that ground would undermine the "essential" or "underlying" values of a free and democratic society.

Sixth, the court took into account the nature of the benefit affected by the classification. ${ }^{114}$ Ms. Kask alleged that Alberta's security for costs rule was unconstitutional. At stake was her access to the administration of justice. ${ }^{115}$ Seventh, Mr. Justice McDonald applied the Oakes approach to s. 1. This was so even though that case involved s. 11(d), as opposed to s. 15(1) of the Charter. Eighth, the fact that the security for costs rule, in so far as it affected non-residents, contravened "a constitutional policy expressed by another Charter right"', namely s. 6(2), was relevant. ${ }^{116}$ The likelihood that the defender of the rule could convince the court that it was passed in response to a pressing and substantial need in a free and democratic society diminishes each time a constitutional value expressed outside of s. 15 is compromised. ${ }^{117}$
110. Id. at 9 .
111. Id. at 10.
112. Id. at 22.
113. Id. at 11-12.
114. Id. at $14 \& 17$.
115. Id. at 14 .
116. Id. at 29.
117. Id. at 29-30. 
With one exception, the writer agrees with Mr. Justice McDonald. It is probably not necessary to introduce the refinement represented by the fifth proposition. Any classification scheme which treats those who are alike differently or those who are not alike the same contravenes s. 15(1). Mr. Justice McDonald believed that only those classification schemes which undermine essential democratic values contravene s. 15(1). This means that forms of discrimination which do not have this effect are not caught by s. 15(1). The writer believes that any law which treats those who are alike differently may undermine the constitutional values protected by s. 15(1) and should only be upheld if $s .1$ is applicable. We differ then not with respect to the effect schemes which undermine constitutional values have, but which classification schemes have that effect. This could be a distinction without a difference if classification systems which treat likes differently are adjudged to undermine essential democratic values.

British Columbia \& Yukon Territory Building \& Construction Trades Council v. British Columbia, ${ }^{118}$ a civil matter, is another important case. British Columbia amended its Labour Code ${ }^{119}$ to eliminate labour strife at its Expo ' 86 site and to promote economic recovery. ${ }^{120}$ The legislation restricted the work places in which the unions could assert non-affiliation clauses. As a result, unlike other unionized construction workers, those who worked at parts of the Expo '86 site had to work alongside non-union labour.

The court, quite properly, initially focussed on the issue of unequal treatment. ${ }^{121}$ It asked "if there [was] an inequality of treatment." 122 This was the proposition the trades council had to establish. ${ }^{123}$ The petitioners argued that "the workers are the same and the work is the same . . ."124 Whether the court was satisfied this was the case is not entirely clear. Various passages present different impressions. When discussing the effects of the challenged law the court wrote, "The effect of this legislation is to set apart construction work which is made subject to a declaration ... and the unionized construction workers who are engaged upon it. . . ,,$_{125}$ This would suggest that the trades council's argument might have been accepted. On the other hand, the court stated, "Unionized workers who are dispatched to a 'separate economic development project' are in a justifiably different category from those who are dispatched to other work. The difference lies not in anything which attaches to them as individuals . . . but in the importance of the work they do to the economic interests of the province generally. ..." 126 This suggests that the court has found workers on parts of the Expo site not to be similarly situated with others working elsewhere. The court was aware of the importance of the

118. Supra n. 7.

119. R.S.B.C. 1979, c. 212.

120. British Columbia, supra n. 7 at 293.

121. Id. at 285.

122. Id.

123. Id.

124. Id.

125. Id. at 292 .

126. Id. at 294. 
"similarly situated" concept. Earlier it had observed, "[S.] 15(1) is not a simplistic guarantee of identical treatment for all. It speaks of equality and must be read in light of the fact that societies have always accepted rules which treat different people in different ways." ${ }^{27}$

Regrettably the court does not unequivocally express itself on this issue. And when it does finally conclude that it is "[un]necessary to proceed to the question of whether [the section] can be reasonably justified under $\mathrm{s} .1$ of the Charter" 128 it does so because the suspect section "does not place an unconstitutional limitation on the equality rights granted to the petitioners pursuant to s. 15(1)." ${ }^{129}$ Would it not have been preferable to simply state that those who work on projects of special economic importance are not similarly situated with those who work elsewhere and that therefore no unequal treatment was involved. Instead, the court attached to s. 15(1) considerations such as proportionality and rationality, which, if appropriate, are only so when considering s. 1. It wrote: "[T]he section is proportionate to the purpose of the legislature and has a rational basis for dealing differently with affiliation clauses where the Lieutenant Governor specifies a separate economic development project, and has not been shown by the petitioners to be unnecessary to the legislative purpose." 130

Smith, Kline \& French Laboratories Ltd. v. Canada ${ }^{131}$ is also noteworthy. The plaintiffs sought a declaration that s. 41(4) of the Patent Act ${ }^{132}$ was unconstitutional. This provision compels the patentee of inventions "intended or capable of being used for medicine or for the preparation or production of medicine" to issue a license to non-patent holders. An equal protection claim was advanced because the holders of medical patents are treated differently from all other patentees who hold exclusive rights to their invention for seventeen years. ${ }^{133}$

Mr. Justice Strayer's interpretation of s. 15 is in part as follows: $:^{34}$

It appears to me that by its express references to certain forms of discrimination, namely "race, national or ethnic origin, colour, religion, sex, age or mental or physical disability", subsection 15(1) is clearly intended to proscribe any distinctions based on those grounds. Any such distinctions, if they are to be defended, must be justified under section 1. It may be that distinctions based on certain grounds such as age may be more readily justified under section 1 but the onus must be on the defender of such a distinction even then.

With respect to other kinds of distinctions which may be made by legislation, it appears to me that no such presumption arises of discrimination and that it is necessary to analyze such distinctions more closely to determine whether they can be regarded as in conflict with subsection 15(1). I do not think it could have been the intention that every distinction drawn by legislation between citizens or classes of citizens should automatically be regarded as "discrimination" within subsection 15(1) and thus immediately cause a shift in onus to a defender of the legislation to justify it under section 1 . It is the business of legislatures to make distinctions for a myriad of reasons and it is inconceivable that every one of these should place on the government, or on everyone else relying on such

127. Id. at 290.

128. Id. at 294.

129. Id. at 294-95.

130. Id. at 294.

131. Supra n. 51.

132. R.S.C. 1970 , c. P-4.

133. Supran. 51 at 192.

134. Id. at 193-94. 
legislation, the onus of showing that it is "justified in a free and democratic society". This would shift to the courts a decisional right and burden which would be unacceptable both to them and the legislatures.

No objection can be taken to Mr. Justice Strayer's assessment of the consequences attendant upon a finding that legislation discriminates on one of the enumerated grounds in s. 15. Clearly, in such circumstances the side supporting the legislation must defend it. If the onus is not discharged s. 1 cannot be invoked.

However, one may disagree with his approach to other types of discrimination. Mr. Justice Strayer's orientation obliged the plaintiff to show that the means were not rationally related to a legitimate governmental objective. ${ }^{135} \mathrm{He}$ made this task difficult to accomplish, holding as follows: ${ }^{136}$

... in judging that question, it is not for the courts to weigh the evidence finely to ascertain if the means chosen are perfect or even the best available. The choice among various possible means is and should remain a political choice: all the Court should do is to see whether the means chosen are patently unsuited or inappropriate for the purpose, and if not then the choice of the legislature should be respected.

With respect, the text of s. 15(1) does not support the dichotomy he proposes. Mr. Justice Strayer has failed to give proper weight to the phrase "in particular" in s. 15. These words suggest that the enumerated grounds are merely examples of what may be prohibited by s. 15(1). They certainly do not justify dramatically different treatment of enumerated and nonenumerated grounds, as favored by Mr. Justice Strayer.

Kask v. Shimizu ${ }^{137}$ did not adopt this dichotomy. It did, however, appeal to Mr. Justice Scollin in Tit v. The Director of Vital Statistics, ${ }^{138}$ a case involving Manitoba's Change of Name Act. ${ }^{139} \mathrm{He}$ held: ${ }^{140}$

It would be unrealistic to classify every distinction as a "breach" of s. 15(1) and to treat every difference in the application of a statute as involving a limitation requiring justification under section 1 . The world of democratic theory may be peopled by legal clones, but the real world is not. For example, in refusing to permit a blind person to drive a car the law is discriminating but not discriminatory. Equal benefit and equal protection of the law simply means that identical facts are the magnet for identical law. When material facts are different, so will be the legal result and in a representative democracy the policy for the selection of material differentiating facts (including rational conditions of eligibility) is for the legislature and not for the courts.

Applying this understanding of s. 15(1) Mr. Justice Scollin concluded that the impugned law was not inconsistent with s. 15(1). As a result he did not consider s. 1.

\section{UNITED STATES CONSTITUTION}

The "equal protection" clause in s. 15(1) of the Charter and its presence in the fourteenth amendment of the United States Constitution, as well as the reference in s. 1 of the Charter to "free and democratic societ[ies],"

135. Id. at 195.

136. Id.

137. Supra n. 2.

138. Supran. 5 at 4-5.

139. S.M. 1982-83-84, c. 56.

140. Supran. 5 at 4. 
invites a careful review of the American experience. ${ }^{141}$ It is a rich one and provides Canadian courts with access to a jurisprudential treasure house.

Obviously, Canadian courts are not bound by decisions of the United States Supreme Court. It is equally true though that any court considering a novel issue will canvas the case law which is available. ${ }^{122}$ In Laporte v. The Queen, ${ }^{143} \mathrm{Mr}$. Justice Hugessen observed, "[E]ven though there is no English or Canadian case directly in point, the matter has arisen before in the United States and, while not binding on me, the decisions of the Courts of that country may always be looked to for guidance."

This orientation has also guided appellate courts. Mr. Justice McIntyre made extensive use of American jurisprudence in $R$. v. Miller, ${ }^{144}$ a case involving a challenge to the death penalty. $\mathrm{He}$ "found it helpful in seeking principles ... which . . . should be considered in a civilized society."145 When Chief Justice Laskin considered the appeal he devoted considerable attention to American authorities confident of their relevance. ${ }^{146}$

There are differences which distinguish Canadian and American constitutional systems. ${ }^{147}$ However, what is significant is the effect these differences have on a particular problem, not the fact that there are differences. As has been argued elsewhere "If the similarities are compelling, the dissimilarities inconsequential, then there is utility in conducting the foreign survey." ${ }^{48}$ And once it is acknowledged that American cases

141. The Queen v. Morgentaler, supra n. 104 at 97; Finkelstein, supra n. 35 at 197-200; Seale, supra n. 27 at 454-55.

142. See Senior v. Holdsworth, Ex p. Independent Television News Ltd. [1976] 1 Q.B. 23 at 24 (C.A.) (obligation of news service to disclose evidence); State v. Clark, 104 N.J. Super. 67, 248 A. 2d 559 (1968) (effect improper medical procedure had on capability of alleged murderer); R. v. Hurley [1967] V.R. 526 at 533-34, 542-43 (S.C.) (limits of the duress defence in criminal law): Narayanan Nambudiripad v. Madras 41 A.I.R. 385 (Madras H.C. 1954) (how high was the wall separating church and state); $R$. v. Naish, supra n. 80 (scope of freedom of religion); Re Wren [1945] O.R. 778 (H.C.) (validity of restrictive covenant).

143. (1972) 8 C.C.C. (2d) 343 at 347 (Que. Q.B.).

144. (1975) 24 C.C.C. (2d) 401 (B.C.C.A.).

145. Id. at 465 .

146. (1976) 31 C.C.C. (2d) 177 at 185.

147. Compare these views of the American and Canadian Supreme Courts. In McGowan v. Maryland, 366 U.S. 420 at 425-26 (1961), Chief Justice Warren wrote: "Although no precise formula has been developed, the Court has held that the Fourteenth Amendment permits the States a wide scope of discretion in enacting laws which affect some groups of citizens differently than others. The constitutional safeguard is offended only if the classification rests on grounds wholly irrelevant to the achievement of the State's objective. State legislatures are presumed to have acted within their constitutional power despite the fact that, in practice, their laws result in some inequality. A statutory discrimination will not be set aside if any state of facts reasonably may be conceived to justify it." The Canadian position adopts the opposite approach. In The Queen v. Oakes, supra n. 2 at 126-127, Chief Justice Dickson concluded: "The onus of proving that a limit on a right or freedom guaranteed by the Charter is reasonable and demonstrably justified in a free and democratic society rests upon the party seeking to uphold the limitation... . The presumption is that the rights and freedoms are guaranteed unless the party invoking $s .1$ can bring itself within the exceptional criteria which justify their being limited. . . . The standard of proof under $s .1$ is the civil standard, namely, proof by a preponderance of probability. . . . Nevertheless, the preponderance of probability test must be applied rigorously."

148. Wakeling, "The Oral Component of Appellate Work" (1979) 5 Dalhousie L. J. 584 at 62526. 
may prove helpful, the value of any particular decision will depend on the quality of its reasons and the thoroughness of the research. ${ }^{149}$

This article will not consider American equal protection case law in any detail. Others have already done this from a Canadian perspective. ${ }^{\text {so }}$ Nonetheless, a summary will be presented to serve as the backdrop for comments relating to the $s .1$ justification standard.

American equal protection jurisprudence has matured in the last half of this century. Until the Warren Court stiffened the justification standards, the equal protection clause had marginal impact on American life. In Lindsley v. Natural Carbonic Gas Co., ${ }^{151}$ the Supreme Court fashioned a justification hurdle so low that even incautious lawmakers could stumble over it. The Supreme Court would invalidate a law "only when it is without any reasonable basis and therefore is purely arbitrary." 152 Further, it held that "[w]hen the classification in such a law is called in question, if any state of facts reasonably can be conceived that would sustain it, the existence of that state of facts at the time the law was enacted must be assumed."153

That deferential standard has not characterized the American judicial response to racial, alienage and nationality classifications. In Loving v. Virginia, ${ }^{154} \mathrm{a}$ Virginia statute prohibiting marriages between persons solely on the basis of racial classifications was under review. The Supreme Court struck it down: "There is patently no legitimate overriding purpose independent of invidious racial discrimination which justifies this classification." 13s In Graham v. Richardson, ${ }^{156}$ the Court declared "that classifications based on nationality or race, are inherently suspect and subject to close judicial scrutiny." To defend its legislation in circumstances when these suspect classifications are utilized the government must demonstrate a compelling purpose and satisfy the court "that the classification is necessary to promote that compelling interest."157

The character of the right affected by a classification scheme not suspect is important. Infringement of certain important constitutional rights (voting, access to the legal system and interstate travel) invokes the same high standard as is applicable to suspect classifications. Shapiro v. Thompson ${ }^{158}$ illustrates this doctrine. Connecticut, Pennsylvania and the District of Columbia withheld welfare payments from persons who were not residents of the jurisdiction for more than one year. States cannot inhibit immigration of indigents into the state. ${ }^{159} \mathrm{Mr}$. Justice Brennnan

149. See generally B. Dickson, "The Role and Function of Judges" (1980) 14 Gazette 138 at 165.

150. See, e.g., Bayefsky, supra n. 27 at 52-59.

151. 220 U.S. 61 (1911).

152. Id. at 78.

153. Id.

154. 388 U.S. 1 (1967).

155. Id. at 11 .

156. 403 U.S. 365 at 372 (1971).

157. J. Nowak, et al., supra n. 28 at 524.

158. 394 U.S. 618 (1969).

159. Id. at 630 . 
held that if the state employs means which incorporate invidious classifications the state must show them "to be necessary to promote a compelling governmental interest. . . ."160

Obviously in America, the classification ground is of special importance. If the classification scheme utilizes race, alienage, nationality, and perhaps other grounds, such as sex, the law which embodies this plan will be invalidated unless the legislative purpose is compelling ${ }^{161}$ or overriding ${ }^{162}$ and the classification necessary to accomplish the authorized legislative goal. Use of other discriminating features has as a consequence a much lower measure of constitutional compliance. Assuming that the statute's purpose is lawful, does the differentiation reasonably promote the lawful goal is the key question.

\section{CONCLUSIONS}

This review of the Canadian experience with the Canadian Bill of Rights and the Canadian Charter of Rights and Freedoms and the American experience with the fourteenth amendment allows one to suggest the following considerations will be borne in mind by courts evaluating s. 1 justification claims:

1. In some circumstances the law will be invalidated if its purpose does not promote a "necessary and desirable social objective"163 or if the means are not "a necessary departure from the general principle of universal application of the law...."164

2. In other circumstances, the law will be declared of no force and effect if it does not have a valid purpose or if "it has [not] been created rationally in the sense that it is . . . arbitrary or capricious. . . "'165 A law will not necessarily be characterized as rational if only some of its means promote the legislative objective. It will not be characterized as rational unless the entire instrument reasonably promotes the legislative goal.

3. The standard set out in point 1 would be invoked if the statute infringed a right or freedom guaranteed in s. 15(1) of the Charter and elsewhere in the Charter. Demanding this confirmation of the importance of the s. 15(1) right or freedom ensures that only the most significant constitutional values enjoy such a high degree of protection. If legislation granted Catholics a tax exemption not available to non-Catholics the point 1 standard would apply. The statute would contravene s. 2(a) protecting religious freedom as well as s. 15(1). It must be remembered that a law may be constitutionally suspect for a number of reasons besides its inconsistency with s. $15 .{ }^{166}$ If so, then the justification standard appropriate for that particular Charter breach would also be applicable.

160. Id. at 634 .

161. Id.

162. Loving v. Virginia, supra $\mathrm{n} .154$ at 11.

163. MacKay v. The Queen, supra n. 7 at 407.

164. Id.

165. Id.

166. Kask v. Shimizu, supra n. 2 at 19. 
4. If the legislation infringes a Charter right guaranteed in s. 15(1) and not elsewhere in the Charter, the standard described in point 1 might be applicable. This would not depend on the basis of the classification being enumerated in s. 15(1). The nine grounds listed in s. 15(1) are not equally questionable bases of legislative classification. ${ }^{167}$ They are illustrations of some grounds of classifications which may prove to be unconstitutional. The words, "in particular" in s. 15 confirm this. Whether or not the test in point 1 will apply will depend on a judicial determination, based on a reading of the Canadian constitutional fabric, that the classification is invidious. In all likelihood such a finding would be made in instances involving race, national or ethnic origin, colour, religion and sex. It is conceivable that other bases of discrimination not listed in $\mathrm{s}$. 15 would warrant the same point 1 treatment.

5. If the legislation uses a classification scheme which is not listed in s. 15 and is not for other reasons adjudged to be invidious, the less demanding justification standard described in point 2 will be used. There is a further consideration which will influence the application of the less demanding standard. As the imprecision of the means increases, so must the importance of the governmental interest. This results because legislation, as it becomes less precise, affects not only persons whose conduct will increase or decrease the likelihood the legislative objective will be attained, but others, whose conduct will not impact on the attainment of the legislative goal. Support for this proposition comes from Mr. Justice McIntyre's opinion that "departure from the concept of equality before the law must not be greater than is necessary for those [legislative ends]. . . "'168

While these five points draw heavily on Mr. Justice McIntyre's opinion in MacKay, his opinion is not authority for them. He did not contemplate distinct justification tests. Nonetheless, aspects of his reasons suggest that the propositions have some merit. Further, these five points are consistent with the general thrust of the American experience and Canadian constitutional principles.

The Supreme Court of Canada's decision in The Queen v. Oakes ${ }^{169}$ confirms that points 1 and 3 are sound and that aspects of the others are as well. Points 1 and 3 are defensible because they spring from the belief that a timid judicial approach to $s .1$ is not appropriate. Chief Justice Dickson made the same point in Oakes when he stated that s. 1 imposes a "stringent standard of justification". ${ }^{170}$ More particularly, Chief Justice Dickson wrote, with respect to legislative ends, that "the objective, which the measures responsible for a limit on a Charter right or freedom are designed to serve, must be of 'sufficient importance to warrant overriding a constitutionally protected right or freedom'. . ." ${ }^{177}$ This standard would

167. Smith, Kline \& French Laboratories Ltd. v. A.G. of Canada, supra n. 51 at 194. Boudreau v. Lynch (1984) 16 D.L.R. (4th) 610 at 615 (N.S.S.C. App. Div.) (sex discrimination is the most odious form of discrimination).

168. MacKay v. The Queen, supra n. 7 at 408.

169. Supra n. 2.

170. Id. at 126.

171. Id. at 128-129. 
appear to be that adopted by Mr. Justice McIntyre in MacKay and in point 1 above. The Chief Justice's approach to legislative means was equally rigorous. He formulated three tests: ${ }^{17}$

First, the measures adopted must be carefully designed to achieve the objective in question. They must not be arbitrary, unfair or based on irrational considerations. In short, they must be rationally connected to the objective. Second, the means, even if rationally connected to the objective in this first sense, should impair "as little as possible" the right or freedom in question. . . . Third, there must be proportionality between the effects of the measures which are responsible for limiting the Charter right or freedom, and the objective which has been identified as of "sufficient importance".

... Even if an objective is of sufficient importance, and the first two elements of the proportionality test are satisfied, it is still possible that, because of the severity of the deleterious effects of a measure on individuals or groups, the measure will not be justified by the purposes it is intended to serve. The more severe the deleterious effects of a measure, the more important the objective must be if the measure is to be reasonable and demonstrably justified in a free and democratic society.

In essence, Oakes warns lawmakers who treat like situated persons differently that they must be prepared to prove that it was done for an important reason and that the means were carefully tailored to promote important legislative ends, so that those whose conduct need not be regulated to achieve the lawmakers goals remains unregulated. This is the thrust of points 1,3 and 4 , as well as a portion of point 5 .

Oakes, is not authority for the proposition that s. 15(1) contemplates more than one standard of review. This is the assumption which is the foundation for the five propositions advanced above. At the same time, it is not authority for the contrary position. Accordingly, the veracity of point 5 has not yet been determined.

\section{v. CONCLUSION}

In order to appreciate the limitations s. 15(1) imposed on legislators, the value of laws which treat likes alike and those not alike differently must be understood. Chief Justice Dickson in Oakes ${ }^{173}$ and Big M. Drug Mart ${ }^{174}$ and Mr. Justice McDonald in Kask ${ }^{175}$ have addressed this theme. In short, they believe that laws which comply with s. 15(1) promote human dignity and respect for Canadian laws and institutions. For this reason, they have fashioned a standard to measure constitutional compliance with s. 15(1) which is onerous. While the standard is difficult to achieve, it is not unrealistic. Rather, it insists that lawmakers exercise their jurisdiction with intelligence and sensitivity. If they consider it necessary to treat those similarly situated differently they must be prepared to defend their decision. This is so whether or not they have fashioned a classification scheme which discriminated on a basis set out in s. 15(1) and whether or not those discriminated against are natural persons or corporations.

172. Id. at 129-130.

173. Id. at 125-126.

174. Supra n. 3 at 337.

175. Supra n. 2 at 6-8. 